Saudi Journal of Medical and Pharmaceutical Sciences

Abbreviated Key Title: Saudi J Med Pharm Sci

ISSN 2413-4929 (Print) |ISSN 2413-4910 (Online)

Scholars Middle East Publishers, Dubai, United Arab Emirates

Journal homepage: https://saudijournals.com

Review Article

\title{
Malaria and COVID 19 Interactions: The Effects of the Collision of Two Giants
}

\author{
Ezenwa-Ahanene Chidiadi ${ }^{1}$, Ifeyinwa Nwogo Chijioke-Nwauche ${ }^{2,4^{*}}$, Emmanuel Wobo ${ }^{1}$, Otokwala Job ${ }^{3}$ and Chijioke $^{2}$ \\ Adonye Nwauche ${ }^{1,4,5}$ \\ ${ }^{1}$ Department of Haematology, University of Port Harcourt Teaching Hospital, Port Harcourt, Rivers State, Nigeria. \\ ${ }^{2}$ Department of Clinical Pharmacy and Management, Faculty of Pharmaceutical Sciences, University of Port Harcourt, Rivers State, \\ Nigeria \\ ${ }^{3}$ Intensive Care Unit, Department of Anaesthesia, University of Port Harcourt Teaching Hospital, Port Harcourt, Rivers State, Nigeria \\ ${ }^{4}$ Centre for Malaria Research and Phytomedicine, University of Port Harcourt, Rivers State, Nigeria \\ ${ }^{5}$ NDDC Professorial Chair on Malaria Elimination and Phytomedicine Research, University of Port Harcourt, Rivers State, Nigeria
}

DOI: $10.36348 /$ sjmps.2021.v07i04.004

| Received: 14.03.2021 | Accepted: 20.04.2021 | Published: 27.04.2021

*Corresponding author: Ifeyinwa Chijioke-Nwauche. Ph.D.

\section{Abstract}

COVID-19 and malaria share similar pathogenic pathways with the angiotensin converting enzyme 2 as a central initiator of signals to stimulate host cellular responses which in some instances result in multi-organ affectation. These signaling proteins are either upregulated or downregulated with the consequences of provoking immune responses with varying tissue damages. The similarities in clinical presentations, associated complications and therapeutic responses to the repurposed medications (anti-malarial drugs being used as anti-viral molecules) for the treatment of the novel disease COVID-19 have stimulated enormous interest in the recent past. The major objectives in this regard are to define the association between these two disease entities and possibly unveil options for interventions. This paper therefore aims at reviewing the molecular interactions which these diseases possibly share in their pathogenesis and phenotypic expressions and make projections for future interventions.

Key words: Malaria, COVID-19, Interactions, Effects, Collision, Giants.

Copyright () 2021 The Author(s): This is an open-access article distributed under the terms of the Creative Commons Attribution 4.0 International License (CC BY-NC 4.0) which permits unrestricted use, distribution, and reproduction in any medium for non-commercial use provided the original author and source are credited.

\section{INTRODUCTION}

\section{Malaria Historical Antecedents}

Malaria predates the prehistoric humans but it is thought to have originated in the tropics, precisely in Africa [1], and it was reported that the African region contributes $94 \%$ of the number of cases and deaths globally [2]. The Italians named the disease 'mal aria' which means foul air in the $18^{\text {th }}$ century [1], while the early Asia-Hindu and Chinese writings made references to periodic fevers [1]. Hippocrates, the Greek Physician, described the clinical manifestations and some of the complications of malaria in the fifth century B.C [1]. Further work by South American researchers later revealed that the bark of the Peruvian Cinchona tree was successfully used for the treatment of intermittent fever in the early $17^{\text {th }}$ century [1]. The active ingredient was subsequently found to be a quinine alkaloid which was isolated in France by 1820 [1].
Malaria parasite is transmitted through mosquito bites with different species of Plasmodium having been identified and these include; P. falciparum (responsible for $>90 \%$ of infections and most dangerous), $P$. malariae ( $<10 \%), P$. ovale $(<10 \%), P$. vivax, and $P$. knowlesi. The Plasmodium parasites undergo asexual division in man and a sexual reproductive cycle in the anopheles mosquito [1].

The global malaria prevalence is about 300500 million cases annually with 23 million of the patients living in Africa [2]. The African region carries a disproportionately high share of the global malaria burden, with $94 \%$ of malaria cases and deaths in 2019 [2]. On the other hand, Nigeria accounts for $25 \%$ of global malaria burden, with the under-5 children and pregnant women constituting the high-risk groups; in addition to accounting for almost $24 \%$ of global deaths from malaria [2]. 


\section{Interaction of malaria parasite \& host cells}

Following mosquito bites, Plasmodium sporozoites are introduced into the peripheral blood and they invade erythrocytes and hepatocytes. Invasion of the erythrocytes is done through some receptors located on the surface of the erythrocytes cell membrane. The cascade of events that occur following the entrance of the Plasmodium into the cell is responsible for the clinical features of malaria. Red blood cells infected with P. falciparum occasionally sequester in the small capillaries and post-capillary venules of some tissues like the brain, lungs, spleen intestine, skin, fat tissue, bone marrow, and skeletal and cardiac muscles [3-10].

\section{The role of Renin-Angiotensin system (RAS) in Plasmodium falciparum invasion of red cells}

Plasmodium invades red blood cells through ACE2 receptors located on the red cell surface. Angiotensin II interacts with ACE2 receptor which converts it to Ang (1-7). Angiotensin-(1-7) binds to its specific receptor Mas which is expressed in the human erythrocyte membrane. A signalling pathway is triggered inhibiting PKA activity. Decreased PKA activity impairs merozoids invasion of the erythrocytes [11].

ACE polymorphisms are related to malaria severity by conferring protection from severe malaria in childhood [11]. Some studies have shown that the D allele of ACE I/D polymorphism and ACE2 $\mathrm{C} \rightarrow \mathrm{T}$ substitution polymorphism which increase Ang II production are associated with mild malaria [11].

\section{COVID -19}

This is a respiratory disease caused by severe acute respiratory syndrome coronavirus 2 (SARS-CoV2). It was first reported in Wuhan city, China in December 2019. This disease has caused a pandemic resulting in over 123,902,242 confirmed cases of COVID-19 and 2,727,837 deaths across the globe [11]. Currently, healthcare delivery worldwide is enduring unprecedented strain. The diagnosis and management of SARS-CoV-2 has also faced some challenges in the malaria endemic zones because of the similarities in symptoms between SARS-CoV-2 and malaria [11].

\section{Pathogenesis of COVID-19 infection}

Severe acute respiratory syndrome Coronavirus- 2 is transmitted through inhalation or contact with infected respiratory droplets [12]. The virus subsequently invades the host human cells by binding to angiotensin-converting enzyme 2 (ACE2) receptor especially on the type 2 alveolar cells in the lungs and other tissues which leads to affectation of the cardiovascular, neurological, haematopoietic, and the Immune system [13]. Coronavirus disease 2019 has impact on many laboratory parameters which have potential clinical and biological significance. (Table 1).

Table-1: Potential clinical and biological significance of abnormal laboratory values in patients with COVID-19 [19]

\begin{tabular}{|l|l|}
\hline Laboratory parameter & Potential clinical and biological significance \\
\hline Lymphopenia & Decreased immunological response to the virus \\
\hline Leucocytosis & Bacterial (super)infection \\
\hline Increased value of monocyte distribution width & Bacterial (super)infection \\
\hline Thrombocytopenia & Severe viral infection/viremia/viral sepsis \\
\hline Increased value of CRP & Consumption (disseminated) coagulopathy \\
\hline Increased value of procalcitonin & Severe viral infection/viremia/viral sepsis \\
\hline Increased value of LDH & Bacterial (super)infection \\
\hline Increased value of aminotransferases & Pulmonary injury and/or widespread organ damage \\
\hline Increased value of bilirubin & Liver injury and/or widespread organ damage \\
\hline Increased value of creatinine & Liver injury \\
\hline Increased value of cardiac troponins & Kidney injury \\
\hline Decreased value of albumin & Cardiac injury \\
\hline Prolongation of prothrombin time & Impairment of liver function \\
\hline Increased value of D-dimer & Activation of blood coagulation and/or disseminated coagulopathy \\
\hline
\end{tabular}

CRP; C-Reactive protein, LDH; Lactate dehydrogenase

\section{The role of ACE2 receptors in SARS-CoV-2 induced cytokine storm}

SARS-CoV-2 spike proteins bind to ACE 2 receptors of numerous target cells like alveolar epithelial cells, macrophages, and blood circulating monocytes [17]. This induces exaggerated proinflammatory events through the activation of transcription nuclear factor kappa B (NFא-B) intracellular signalling pathway leading to over expression of pro-inflammatory cytokines and chemokines like IL-1B, IFN- $\gamma$, IL-6, IL-8, IL-12, IL-4, MCP1 and IL-10 in the serum [18]. Higher levels of other pro-inflammatory mediators including interleukin (IL)-2, IL-7, IL-10, tumour necrosis factor (TNF), granulocyte colony stimulating factor (G-CSF), monocyte chemoattractant protein-1 (MCP1; also known as CCL2), macrophage inflammatory protein 1 alpha (MIP1 $\alpha$; also known as CCL3), CXC-chemokine 
ligand 10 (CXCL10), C-reactive protein, ferritin, and D-dimers in serum have been in studies [19]. These findings suggest that severe COVID-19 can be identified by the presence of cytokine release syndrome, which is a disorder induced by cytokine storms [20]. The excessive pro-inflammatory mediators cause vascular endothelial dysfunction which further leads to excessive thrombin generation and reduced fibrinolysis thereby creating a hypercoagulable state [21].

Table-2: Comparison of pathophysiology of malaria and COVID-19 [21]

\section{COVID-19}

SARS-CoV 2 uses ACE2 receptor to achieve cell entry

SARS-CoV 2 spike proteins bind to ACE 2 receptors, particularly the type 2 alveolar cells.

Polymorphism or deletion of ACE2 gene plays an important role in geographical variations with respect to the prevalence of COVID-19.

They induce pro-inflammatory events through the activation of transcription nuclear factor kappa B intracellular signaling pathway leading to over expression of cytokines and chemokines (Cytokine storm).

\section{Malaria}

Renin-Angiotensin System (RAS) derived peptides including ANG I, ANG II, MAS, ACE and ACE 2 may play a role in parasite development and in the regulation of the host immune response.

Malaria Associated symptoms may be controlled by host specific signalling pathways (e.g. PKA)that influence parasite invasion and development

ACE polymorphisms are associated with malaria severity i.e. they confer protection from severe malaria in childhood-higher levels of Ang II protect against cerebral malaria

Cytokine storm involving the ACE2 receptors in the bone Marrow and peripheral blood ultimately lead to depressed marrow function especially Lymphopenia and thrombocytopenia.

Table-3: Peculiarities between COVID-19 and Malaria [21]

\begin{tabular}{|c|c|c|}
\hline & COVID-19 & Malaria \\
\hline Possible presentations & $\begin{array}{l}\text { Asymptomatic, Presymptomatic, mild } \\
\text { to critical, rapid progression to severe } \\
\text { disease }\end{array}$ & $\begin{array}{l}\text { Asymptomatic, mild to critical, rapid } \\
\text { progression to severe disease }\end{array}$ \\
\hline Common symptoms & $\begin{array}{l}\text { Flu-like symptoms fever, headache, } \\
\text { chills, myalgia, vomiting; diarrhoea } \\
\text { and cough (commoner in children for } \\
\text { malaria) }\end{array}$ & $\begin{array}{l}\text { Flu-like symptoms fever, headache, chills, } \\
\text { myalgia, vomiting; diarrhoea and cough } \\
\text { (commoner in children for malaria) }\end{array}$ \\
\hline $\begin{array}{l}\text { Severe/Critical } \\
\text { symptoms }\end{array}$ & $\begin{array}{l}\text { Persistent pain or pressure in the chest } \\
\text { ARDs } \\
\text { Hypoxia } \\
\text { Cyanosis } \\
\text { Disseminated intravascular coagulation } \\
\text { Death }\end{array}$ & $\begin{array}{l}\text { Pulmonary complications ARDS } \\
\text { Hypoxia, } \\
\text { Cyanosis } \\
\text { Multiorgan dysfunction and disseminated } \\
\text { intravascular coagulation death } \\
\text { Dehydration from excessive Vomiting } \\
\text { Severe anaemia } \\
\text { Prostration } \\
\text { Convulsion(unconsciousness) } \\
\text { Hyperbilirubinemia }\end{array}$ \\
\hline Other symptoms & Loss of taste and smell & Taste impairment - Bitter or metallic taste \\
\hline Outcome & $\begin{array}{l}\text { Fatal in elderly, medical co- } \\
\text { morbidities, mild in children } \\
\text { More in densely populated / urban } \\
\text { slums and in racial minorities (blacks, } \\
\text { Hispanics) }\end{array}$ & $\begin{array}{l}\text { Fatal in children, pregnant women, immune- } \\
\text { compromised } \\
\text { More in rural and densely populated / urban } \\
\text { slums }\end{array}$ \\
\hline Treatment & $\begin{array}{l}\text { Empirical treatment with } \\
\text { Hydroxychloroquine/chloroquine, } \\
\text { Azithromycin, Ivermectin and other } \\
\text { adjuvants }\end{array}$ & $\begin{array}{l}\text { Chloroquine in countries where Plasmodium is } \\
\text { still sensitive and artemisinin combination } \\
\text { therapy in countries where there is chloroquine } \\
\text { resistance }\end{array}$ \\
\hline
\end{tabular}




\section{Hypotheses on the relationship between malaria endemicity and coronavirus severity}

Evolutionary adaptive changes such as variants of the ACE2 receptor, which is used by the coronavirus and malaria to infect cells, may protect populations from SARS-CoV-2 in malaria endemic regions [23]. Wide use of chloroquine and its derivative (hydroxychloroquine) in the prevention and treatment of malaria in sub-Saharan Africa may have also contributed to the protection against SARS-CoV-2 infection [24]. The mechanisms of action of these drugs include interfering in the glycosylation process of cellular receptors of coronavirus and increasing the endosomal $\mathrm{pH}$ thus inhibiting the fusion of the virus on the cells [25].

\section{Use of Artemisinin in COVID-19}

The COVID-19 pandemic has brought to light the need for continual search for medicines that have multiple pharmacological activities. One of such medicines or agents is artemisinin. Artemisinin and its derivatives is currently the mainstay for treatment of malaria albeit in combination with partner drug. The similarity of symptomatic presentation of malaria and COVID-19 early stages triggered a lot of trial use of known antimalarial drugs for the treatment of COVID19.

In a non-randomized and controlled trial, patients with established diagnosis of Covid -19 were treated with Artemisinin-piperaquine against a controlled group treated with hydroxychloroquine. Participants were adult patients between ages 18 and above with confirmed SARS-CoV-2 infection in upper respiratory tract specimens by real-time reversetranscriptase-polymerase-chain-reaction (RT-PCR). The primary outcome were the time taken to reach undetectable levels of severe acute respiratory syndrome-coronavirus-2 (SARS-CoV-2) and the percentage of participants with undetectable SARSCoV-2 on days $7,10,14$, and 28 . Outcome of study established a significantly shorter time to reach undetectable SARS-CoV-2 in patients with mild to moderate COVID-19 treated with Artemisininpiperaquine compared to the control group treated with Hydroxychloroquine [26].

\section{Impact of COVID-19 pandemic on malaria intervention programmes in Africa}

The global malaria burden has been reduced in recent times following successful malaria control and intervention programmes. However, withdrawal of these interventions is likely to cause rapid resurgence of malaria and this threatens vulnerable population of pregnant women and children [27]. The COVID-19 pandemic brought about to a great extent a distraction from malaria management resulting in reduced availability of or distribution of malaria test kits. This was mainly due to lockdown-related disruptions to the global supply chain [28]. Services such as seasonal malaria chemoprevention (SMC), distribution of insecticide treated nets (ITNs), malaria treatment and testing are disturbed due to risks of the COVID-19 infection to health workers who provide services during the pandemic [29]. Additionally, there were increased barriers to accessing healthcare during outbreaks following reduced transportation during lockdown. Some persons, especially daily wages earners had limited resources to pay to access the health facilities. Other negative impacts of COVID-19 on malaria intervention efforts include:

- Impairment of the malaria prevention campaign programs.

- Patients may stop visiting health facilities for malaria treatment as a result of fear of exposure to COVID-19 infection.

- Reduced accessibility of hospital facilities by patients due to lockdown of the regions.

- Diversion of government's attention from other pressing health challenges to COVID-19.

- Decreased availability of hospital infrastructure and consumables for management of severe malaria.

- Diversion of the inadequate health workforce towards COVID-19 care causing reduced manpower and attention to other illnesses like malaria.

- Widespread absenteeism due to illness of health workers.

- Absenteeism following restriction of human and vehicular movement by government.

- Misdiagnosis of malaria as COVID-19 by health workers.

- Missed diagnosis of malaria in COVID-19 patients.

- Inadequate personal protective equipment available for healthcare workers to manage other diseases.

- Impairment of medical supply chain due to deficiencies in logistics.

Studies had predicted that if concerted efforts are not made to strength the malaria control programmes, COVID-19-related disruption to malaria control in Africa could almost double malaria mortality in 2020, and potentially lead to even greater increases in subsequent years [30].

\section{The role of Chloroquine (CQ) and Hydroxychloroquine} (HCQ) in Malaria and COVID-19 comorbidities

The current knowledge of the role of both CQ and HCQ may be attributable to its wide use in malaria endemic countries. The somewhat chimeric or diverse inverse relation between COVID-19 and malaria prevalence may be referable to reports that these medications may have both preventive and curative effects against SARS-CoV-2 virus through several mechanisms: 
i. Immune modulation mechanisms that halt the disease progression and inhibiting cytokines storm by reducing $\mathrm{T}$ cell activation;

ii. Changing cellular $\mathrm{pH}$ and preventing viral replication;

iii. CQ has demonstrated antiviral activity in both infected and healthy cells which may apply also to HCQ.

iv. (iv)They also inhibit the virus binding to its target host receptors (ACE2) as well as the membrane fusion [31]

v. (v)The drugs can also alter glycosylation of ACE2 receptors by preventing receptor virus interaction, thereby reducing the binding affinity the virus spike proteins and cell receptors [31].

Through these processes, the drugs prevent viral entry into the cells. SARS-CoV-2 virus gains entry to the host cells through cellular structures known as endosomes. HCQ and CQ also achieve high concentrations within these lysosomes which cause an increase of $\mathrm{pH}$ from the low value obtained in the cell structures. The resultant effect is that the fusion of the virus with the endosomes becomes terminated [32]. The high $\mathrm{pH}$ creates an unfriendly environment for viral replication [33].

\section{CONCLUSION}

The significance of the shared peculiarities of the pathogenesis, immunomodulation and presentations and co-morbidities and mortalities of both SARS-CoV2 and malaria infections, with the attendant impact on the logistics framework and architecture underline the need for urgent measures to mitigate its impact on critical global public health indices. In this regard, this ongoing pandemic may be beneficial in throwing up the opportunity to explore the possible role of previously well-documented anti-malarial drugs and molecules such as Artemisinins with reported anti-viral properties in the future treatment of SARS CoV-2 infections.

\section{REFERENCES}

1. Ajayi, I. O., Ajumobi, O. O., \& Falade, C. (2020). Malaria and COVID-19: commonalities, intersections and implications for sustaining malaria control. The Pan African Medical Journal, 37(Suppl 1).

2. Al- Bari, M. A. A. (2017). Targeting endosomal acidification by chloroquine analogs as a promising strategy for the treatment of emerging viral diseases. Pharmacology research \& perspectives, 5(1).

3. Masson, P., \& Reanim, A. F. A. (1995). Cath (t (risme art (riel et mesure invasive de la pression art (rielle en anesthdsie-r (animation chez I'adulte. Ann Fr Anesth Reanim, 14, 444-453.
4. Carreira, T., Lopes, S., \& Maia, E. (2007). The "febrifuge principle" of cinchona barks. In 38th International Congress for the History of Pharmacy, Sevilla September 19-22 2007.

5. Cox FE. History of the discovery of the malaria parasites and their vectors. Parasites \& vectors. 2010 Dec;3(1):1-9.

6. Dhangadamajhi, G., Mohapatra, B. N., Kar, S. K., \& Ranjit, M. (2010). Gene polymorphisms in angiotensin I converting enzyme (ACE I/D) and angiotensin II converting enzyme $(\mathrm{ACE} 2 \mathrm{C} \rightarrow \mathrm{T}$ ) protect against cerebral malaria in Indian adults. Infection, Genetics and Evolution, 10(2), 337-341.

7. Di Gennaro, F., Marotta, C., Locantore, P., Pizzol, D., \& Putoto, G. (2020). Malaria and COVID-19: Common and different findings. Tropical medicine and infectious disease, 5(3), 141.

8. Franke-Fayard, B., Fonager, J., Braks, A., Khan, S. M., \& Janse, C. J. (2010). Sequestration and tissue accumulation of human malaria parasites: can we learn anything from rodent models of malaria?. PLoS Pathog, 6(9), e1001032.

9. Gallego-Delgado, J., \& Rodriguez, A. (2014). Malaria and hypertension. Another co-evolutionary adaptation?. Frontiers in cellular and infection microbiology, 4, 121.

10. Giles, H.M. (1993). Historical outline. In Giles HM, Warrel DA, eds. Bruce-Chwatts Essential malariology, $3^{\text {rd }}$ edition Oxford University Press, London: 1-11.

11. Hamming, I., Timens, W., Bulthuis, M. L. C., Lely, A. T., Navis, G. V., \& van Goor, H. (2004). Tissue distribution of ACE2 protein, the functional receptor for SARS coronavirus. A first step in understanding SARS pathogenesis. The Journal of Pathology: A Journal of the Pathological Society of Great Britain and Ireland, 203(2), 631-637.

12. Hojyo, S., Uchida, M., Tanaka, K., Hasebe, R., Tanaka, Y., Murakami, M., \& Hirano, T. (2020). How COVID-19 induces cytokine storm with high mortality. Inflammation and Regeneration, 40(1), 1-7.

13. Huang, C., Wang, Y., Li, X., Ren, L., Zhao, J., Hu, Y., \& Cao, B. (2020). Clinical features of patients infected with 2019 novel coronavirus in Wuhan, China. The lancet, 395(10223), 497-506.

14. Hussein, M. I. H., Albashir, A. A. D., Elawad, O. A. M. A., \& Homeida, A. (2020). Malaria and COVID-19: unmasking their ties. Malaria Journal, 19(1), 1-10.

15. Li, G., Yuan, M., Li, H., Deng, C., Wang, Q., Tang, Y., \& Song, J. (2021). Safety and efficacy of artemisinin-piperaquine for treatment of COVID19: an open-label, non-randomised and controlled trial. International journal of antimicrobial agents, 57(1), 106216.

16. Lippi, G., \& Plebani, M. (2020). The critical role of laboratory medicine during coronavirus disease 
Ezenwa-Ahanene Chidiadi et al., Saudi J Med Pharm Sci, Apr, 2021; 7(4): 185-190

2019 (COVID-19) and other viral outbreaks. Clinical Chemistry and Laboratory Medicine (CCLM), 58(7), 1063-1069.

17. Liu, P. P., Blet, A., Smyth, D., \& Li, H. (2020). The science underlying COVID-19: implications for the cardiovascular system. Circulation, 142(1), 68-78.

18. Malaria Prevention Pushes Forward in Africa Despite Pandemic. (2020). Ashley Stumvoll December 30, 2020. Medscape Pharmacists, Available at https://www.medscape.com/viewarticle/943392

19. McIntosh, K., Hirsch, M. S., \& Bloom, A. (2020). Coronavirus disease 2019 (COVID-19): Epidemiology, virology, and prevention. Lancet. Infect. Dis, 1, 2019-2020.

20. Napoli, P. E., \& Nioi, M. (2020). Global spread of coronavirus disease 2019 and malaria: an epidemiological paradox in the early stage of a pandemic.

21. Packard, R. M. (2007). The making of a tropical disease: a short history of malaria. JHU Press.

22. Putra, T. R. I. (2011). Malaria dan permasalahannya. Jurnal Kedokteran Syiah Kuala, 11(2), 103-114.

23. Rogerson, S. J., Beeson, J. G., Laman, M., Poespoprodjo, J. R., William, T., Simpson, J. A., \& Price, R. N. (2020). Identifying and combating the impacts of COVID-19 on malaria. BMC medicine, 18(1), 1-7.

24. Saab, Y. B., Gard, P. R., \& Overall, A. D. J. (2007). The geographic distribution of the ACE II genotype: a novel finding. Genetics Research, 89(4), 259-267.

25. Silva, L. S., Silva-Filho, J. L., Caruso-Neves, C., \& Pinheiro, A. A. S. (2016). New concepts in malaria pathogenesis: the role of the renin-angiotensin system. Frontiers in cellular and infection microbiology, 5, 103.
26. King, C. H. (2000). Hunter's Tropical Medicine and Emerging Infectious Diseases, Edited by GT Strickland. Philadelphia: WB Saunders, 2000. 1192 pp, illustrated. \$165.00.

27. Talman, A. M., Domarle, O., McKenzie, F. E., Ariey, F., \& Robert, V. (2004). Gametocytogenesis: the puberty of Plasmodium falciparum. Malaria journal, 3(1), 1-14.

28. Terpos, E., Ntanasis- Stathopoulos, I., Elalamy, I., Kastritis, E., Sergentanis, T. N., Politou, M., ... \& Dimopoulos, M. A. (2020). Hematological findings and complications of COVID- 19. American journal of hematology, 95(7), 834-847.

29. Thompson, C. J. S. (1928). The History and Lore of Cinchona. British Medical Journal, 1188-1190.

30. Vincent, M. J., Bergeron, E., Benjannet, S., Erickson, B. R., Rollin, P. E., Ksiazek, T. G., ... \& Nichol, S. T. (2005). Chloroquine is a potent inhibitor of SARS coronavirus infection and spread. Virology journal, 2(1), 1-10.

31. Weiss, D. J., Bertozzi-Villa, A., Rumisha, S. F., Amratia, P., Arambepola, R., Battle, K. E., ... \& Gething, P. W. (2021). Indirect effects of the COVID-19 pandemic on malaria intervention coverage, morbidity, and mortality in Africa: a geospatial modelling analysis. The Lancet Infectious Diseases, 21(1), 59-69.

32. WHO Coronavirus (COVID-19) Dashboard. https://covid19.who.int/ Accessed 04,04,2021.

33. World Health Organization. (2019). The "World malaria report 2019" at a glance. World Health Organization, Geneva, Switzerland.

34. Zhou, D., Dai, S. M., \& Tong, Q. (2020). COVID19: a recommendation to examine the effect of hydroxychloroquine in preventing infection and progression. Journal of Antimicrobial Chemotherapy, 75(7), 1667-1670. 